\title{
嚗ガラス用ガラス熔解タンクの混合特性について
}

\author{
岸上弘 \\ (東洋ガシス技術部)
}

\section{Mixing Character of Glass-melting Tank for Container Manufacturing}

\author{
By \\ Hiromu KISHIGAMI \\ (Toyo Glass Co. Ltd, Kawasaki, Kanagawa)
}

\begin{abstract}
Mixing function of glass-melting tank is of most important for obtaining high homogeneity of glass. It was assumed that the mixing process developing in glass tank is a kind of diffusion process which is caused by mixing action mainly resulting from thermal and mechanical currents. A fundamental differential equation involving the "mixing diffusion coefficients", $k_{x}$, was proposed for discussing the mixing charater of a given tank.

The numerical value of $k_{x}$ could be computed by applying a few practical values such as the dimension of tank, the axial mean velocity of glass flow and the time spent till the tracer concentration gets a maximum, $T_{\max }$, to an equation obtained one of the solutions of the differential equation mentioned above.

Variation of any physical value of glass pulled out during operation is characteristically affected by the values of $k_{x}$ and pull rate imposed on the tank. Hence, the featuer of the physical value-time curve is characterized by $k_{x}$ and $T_{\max }$ as the factors dominantly controlling the mixing effect of glass tank, which gives some fruitful suggestions concerning the mixing character of the tank.

[Received May 29, 1970]
\end{abstract}

\section{1. 緒 言}

タンク宰についての石, 泡, コード, 生地の不均一性 など, ガラ久容器の久点関寸る原因は数多くある。こ つうち, 熔解空の容量化対する取出量の比率, 熔解窯内 のガラスの混合の庋合，または Dog house に投入され る原料成分の変動もまた上記の久点を引起す原因であ る.これらの因果関係を究明するた好，著者はタンク 䕓の混合特性について研究した。

これまでにタンク窯内の熔融ガラスの挙動について, Lokay) は単にトレーサ一実験学行ない, Cooper ${ }^{2)}$ は 篤内学数個に区分し，それぞれの cell で混合し， cell 私ら cell へと Piston flow 功起ると考えた。こ机惊丁 度筧内でバブリングを行なった場合とかフィーダーでス タラーを使用した場合などには適用されるが，一般の箱 そついては完全には当てはまらない。また Platt" 入されたバッチ成分に対する応答は測定の時点で一階の 微分方程式で表わされると考えた。しかし，input 亿対 卞る mode time を変えないで, 任意の測定場所に怙け

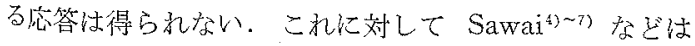
混合流れを考え，モデル実験で無理なく宰内の流れを説 明した。

著者も後者と同じ考えに立台広い意味で“混合を伴う 流れ”であると考え，笑際のタンク害についてトレーサ
一実験亦るい治色替え実験を試み上記の理論を多角的に 検討した。

\section{2. 理 論}

投入口から送り込まれたバッチがガラス化したあと， タンク中の愹融ガラスと混り合っていく過程は，洤度勾 配に基づく真の意味での搪散のほかに，熱的拉よび機械

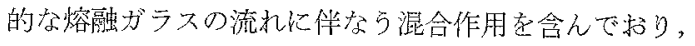
かつ後者がむしろその過程の決定的な要素となっている が，それは，広い意味で搪散的で亦るといえる。そこ で，この過程を混合流れ (mixing-flow) と呼ぶことと する。

真の意味での拡散は取出の時点に祘いても半径数ミリ メートルを超えることのないごく限られた範囲内の現象 である。したがって，ここで混合流れを取扱う以上，真 の拡散は考えないるとする。

いま，三次空間 $x, y, z$ において，熔解がラスが混合 しながら流れ，それ伴なって物理量 $S$ ( $S$ 注，比重， コードまたはガラス原潾中の任意の成分など，いかなる 物理量であってもよい）が時間 $t$ とともに変化する場 合を考光る。

$x, y, z$ 万向向速度成分を $u_{x}, u_{y}, u_{z}$ とし, 混合拡散 係数 (mixing diffusion coefficient) $k$ (測定対象 $S$ 
と無関係に濃度搪散のディメンジョンを有する）とすれ 隹次式が成立する

$$
\begin{gathered}
k_{x}(T) \frac{\partial^{2} S}{\partial x^{2}}+k_{y}(T) \frac{\partial^{2} S}{\partial y^{2}}+k_{z}(T) \frac{\partial^{2} S}{\partial z^{2}} \\
-u_{x} \frac{\partial S}{\partial x}-u_{y} \frac{\partial S}{\partial y}-u_{z} \frac{\partial S}{\partial z}=\frac{\partial S}{\partial t} \quad \ldots . .
\end{gathered}
$$

ただし $T$ は温度で，それぞれ $x, y, z$ の関数であ る.

\section{1 デル夕関数の応答}

今回の実験では inputと output のみ老測定対象と しているのでかなり粗い近似法かも知れないが，y，z方 向の流れや流系内の温度分布を無視すると(1) 式 ${ }^{4) ~ 7) ~}$

$$
k_{x} \frac{\partial^{2} S}{\partial x^{2}}-u_{x} \frac{\partial S}{\partial x}=\frac{\partial S}{\partial t}
$$

$t$ を変数とする単位パルスを $\delta(t)$ とした場合 条件

$$
\begin{aligned}
& t<-\frac{\delta t}{2}, x \geqq 0 \text { で } S=S_{0} \\
& -\frac{\delta t}{2} \leq t \leq \frac{\delta t}{2}\left\{\begin{array}{l}
x=0 \text { で } S=\bar{S} \\
x>0 \text { で } S=S_{0}
\end{array}\right.
\end{aligned}
$$

ただし，集中 input $\bar{S}$ は $x=0$ (バッチ投入口)におい $\tau, t=0$ (投入時) を中心に $t \delta t / 2$ の時間带で，一定 な分布関数 $S_{a}(t)$ (単位時間当たり投入寸る input の 量）学有寸る。そして $\delta t \rightarrow 0$ とした極限で次式孝満足 するものと考えられる。

$$
\bar{S}=\lim _{\delta t \rightarrow 0} \int_{-(\delta t / 2)}^{+(\delta t / 2)} S_{a}(t) d t=\lim _{\delta t \rightarrow 0} S_{a}(0) \delta t
$$

したがって分布関数 $S_{a}(t)$ は次式で与完られる。

$$
S_{a}(t)=\bar{S} \delta(t)
$$

上記の条件在満是する (2) 式の解は

$$
S-S_{0}=\frac{x \exp \left\{-\frac{\left(x-u_{x} t\right)^{2}}{4 k_{x} t}\right\}}{2 \sqrt{\pi k_{x} t^{3}}} \vec{S}
$$

また，原料投入位置から取出までの距離 $x=L$ に拉 いて，S加 peak 值になるまでの時間 $T_{\max }$ 学求める。

(5) 式管微分して $\partial S / \partial t=0 よ り$

$$
T_{\text {max }}=\frac{\sqrt{9 k_{x}^{2}+u_{x}{ }^{2} L^{2}}-3 k_{x}}{u_{x}^{2}}
$$

$S$ の最大值 $S_{\max }$ は

$$
S_{\max }=S_{0}+\frac{L \exp \left\{\frac{\left(L-u_{x} T_{\max }\right)^{2}}{4 k_{x} T_{\max }}\right\}}{2 \sqrt{\pi k_{x} T_{\max }^{3}}} \bar{S} \cdots
$$

となる。

$x=L, u_{x}, T_{\max }$ が与方られれば混合拡散係数 $k_{x}$ は

$$
k_{x}=\frac{L^{2}-u_{x}{ }^{2} T_{\max }^{2}}{6 T_{\max }}
$$

から求少られ。

\section{2 単位関数および任意関数の応答}

タンク筌の色替えを行ならとき,物理量 $S$ (例えば比 重) の変化存求めるには単位関数 $E(t)$ のインディシャ ル応答がわかる必要がある。
条件 $t<0, x \geqq 0$ のとき, $S=S_{0}$

$$
t \geq 0, x=0 \text { で } S=S_{i} E(t)
$$

のもとで (2) 式孝解くと

$$
\begin{aligned}
S= & \frac{S_{i}}{2}\left\{\operatorname{erfc}\left(\frac{x}{2 \sqrt{k_{x} t}}-\frac{u_{x}}{2} \sqrt{\frac{t}{k_{x}}}\right)+\exp \left(\frac{u_{x}}{k_{x}} x\right)\right. \\
& \left.\times \operatorname{erfc}\left(\frac{x}{2 \sqrt{k_{x} t}}+\frac{u_{x}}{2} \sqrt{\frac{t}{k_{x}}}\right)\right\}+S_{0} \cdots \cdots(9)
\end{aligned}
$$

次に, input の物理量 $S$ が時間とともに変動する任意 の関数が与えられた場合の output の物理量の変化を求 め。

$$
\begin{aligned}
& \text { 条件 } t<0, x>0 \text { のとき } S=S_{0} \text { （一定） } \\
& t \geqq 0, x=0 \text { で } S=f(t)
\end{aligned}
$$

のもとで，(2) 式起解く、ただし， $x=0$ に拉ける条件

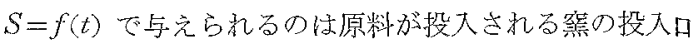

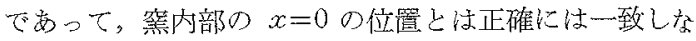
い, しかし投入原料が熔解し, 取出に到辤の長さに比 して上記の条件の差は無規して考えるものと古。

$$
\begin{aligned}
S= & \frac{1}{2} \int_{0}^{t} \frac{d f(\tau)}{d \tau} \exp \left(\frac{u_{x}}{2 k_{x}} x\right)\left\{\exp \left(-\frac{u_{x}}{2 k_{x}} x\right) \operatorname{erfc}\right. \\
& \left(\frac{x}{2 \sqrt{k_{x}(t-\tau)}}-\frac{u_{x}}{2} \sqrt{\frac{t-\tau}{k_{x}}}\right) \\
& +\exp \left(\frac{u_{x}}{2 k_{x}} x\right) \operatorname{erfc}\left(\frac{x}{2 \sqrt{k_{x}(t-\tau)}}\right. \\
& \left.\left.+\frac{u_{x}}{2} \sqrt{\frac{t-\tau}{k_{x}}}\right)\right\} d \tau+S_{0} \ldots \ldots \ldots \ldots \ldots \ldots \ldots
\end{aligned}
$$

を得る。ただし，積分範囲は $t$ について $0 \sim \infty て ゙ ， ~$ は $f(\tau)$ についての時間で, $0 \sim t$ の範東である.

\section{3. 实験および計算結果}

\section{1 トレーサー実験}

$\mathrm{Li}_{2} \mathrm{O}$ をトレーサーとする実験をタンク䈍 $(\mathrm{A})$ 一ータン クの長さ $L=12.6 \mathrm{~m}$, 容量 $C=148.4 \mathrm{t}$, 取出量 $H=$

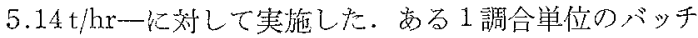
に $54 \mathrm{~kg}$ の炭酸リチりム $\left(\mathrm{Li}_{2} \mathrm{O}\right.$ として $\left.21.9 \mathrm{~kg}\right)$ を添 加し，このバッチ投入後の時間の経過に対して，取り出 されるガラス中の $\mathrm{Li}_{2} \mathrm{O}$ 濃度の測定定行なった。

トレーサー実験における測定結果を図-1の○印で示

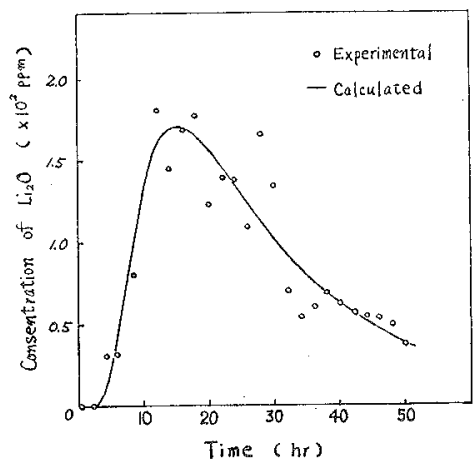

Fig. 1. Concentration variation of $\mathrm{Li}_{2} \mathrm{O}$ in glass pulled out when $\mathrm{Li}_{2} \mathrm{O}$ was added as a flow tracer. 
す.

上記のパターンについて, タンク窝内の平均流速 $u_{x}$ 扔よび混合拡散係数 $k_{x}$ の值を求めるため (5) 式と $\mathrm{Li}_{2} \mathrm{O}$ の総量を用い， $u_{x}$ と $k_{x}$ を変化させ計算值と実測 值との差の $\sigma$ をとり，。が最小值になるような $u_{x}$ と $k_{x}$ 起採用して実験做に最多近い曲線を選んだ。図-1の 实線で示士.

その結果 $k_{x}=1.34 \mathrm{~m}^{2} / \mathrm{hr}, u_{x}=0.410 \mathrm{~m} / \mathrm{hr}$ の場合で $\sigma=23.88 \mathrm{ppm}$ で岕った.

$u_{x}$ を求める別法として， $L$ (筣の長さ $\mathrm{m}$ ) , $H$ (取出 量 $\mathrm{t} / \mathrm{hr}), C$ (签の容量 $\mathrm{t}$ ) と稆くと, タンク董内の生 地の平均速度 $u_{a}(\mathrm{~m} / \mathrm{hr})$ 峘

$$
u_{a}=\frac{L H}{C}
$$

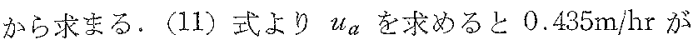
得られ， $u_{x}=0.410 \mathrm{~m} / \mathrm{hr}$ にかなり近似した值を示す。

次に，(6) 式と（7）式から $T_{\max }$ ととのときの $S_{\max }$ を求为ると $T_{\max }=15 \mathrm{hr}, S_{\max }=1.72 \times 10^{2} \mathrm{ppm}$ 学得 る.上記の結果 $L=12.6 \mathrm{~m}, u_{x}=0.410 \mathrm{~m} / \mathrm{hr}, k_{x}=1.34$

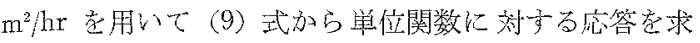
め庆。図-5 にその結果索示す, pull $5.14 \mathrm{t} / \mathrm{hr}$ の場合功 それである。この曲線仙哭（A）について色替時での色 調の変化京たは比重の変化を表わすパターンである.

\section{2 原料組成の饻動亡比䨪変動}

原料珪砂汇含をれる水分の変動は，引き苏价られるガ ラス生地の比重に対して，どのような影響を与えるで市 ろうか. 珪砂中の含有水分が $1 \%$ 変化与ると, その組成 变動に伴なら比重変動㤝 $1.40 \times 10^{-3} \mathrm{~g} / \mathrm{cm}^{3}$ になる。

操業中の十分に長い期閒のガラスの平均比重 $S_{w}$ を基 準としたとき，㪡に投入される原料がガラス化した場合 に生ずべき比重変動牥次式

$$
P=1.40 \times 10^{-3} \times W
$$

で表わされる、ただし，W は珪秒中に含まれる平均水 分加求めた変動の \%で交る。

水分含有率梳図-2 亿示す上らに, バッチ毎に不連続 な值をもつので（12）式によって換算し得られるガラス 比重も不連続になる。したがって，連続な関数とは異な り, 求为る微分值の精度它評価すること注困難である。

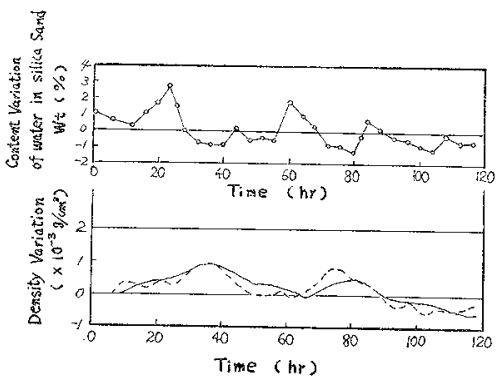

Fig. 2. Water content variation of silica sand used and density variation of glass pulled out.
よってここでは (10) 式の右辺に関して

$$
\begin{aligned}
S= & \frac{1}{2} \sum_{m=0}^{m} \Delta f \exp \left(\frac{u_{x}}{2 k_{x}} x\right)\left\{\exp \left(-\frac{u_{x}}{2 k_{x}} x\right)\right. \\
& \times \operatorname{erfc}\left(\frac{x}{2 \sqrt{k_{x} \Delta t(m-p)}}-\frac{u_{x}}{2} \sqrt{\frac{\Delta t(m-p)}{k_{x}}}\right) \\
& +\exp \left(\frac{u_{x}}{2 k_{x}} x\right) \times \operatorname{erfc}\left(\frac{x}{2 \sqrt{k_{x \Delta} t(m-p)}}\right. \\
& \left.\left.+\frac{u_{x}}{2} \sqrt{\frac{\Delta t(m-p)}{k_{x}}}\right)\right\}+S_{0} \ldots \ldots \ldots \ldots \ldots \ldots(13
\end{aligned}
$$

のように単に，内聥式 Newton 微分法の第 1 項学採用 するにとどめた。ただし， $t=m \Delta t, \tau=p \Delta t, \Delta f=f_{p+1}$ - $f_{p}$ で岕る。

上式から， $t<0$ における窟内のガラスの比重を $S=$ $S_{0}$ と就き, 3.1 節で得た窝の混合特性值 $u_{x}=0.41 \mathrm{~m} /$

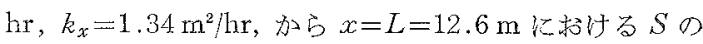
值 (ガラスの比重) 䒚数值計算する. 図-2 にその結果 を示す、実線，点線はそれぞれ計算值，実測值である。 凧者はかなりよく一致している。

\section{3 色替元実験}

バブリングを施している筧（B）について色替え実験 を行なった。䆝のディメンジョンは $L=8.3 \mathrm{~m}, H=$ $0.333 \mathrm{t} / \mathrm{hr}$ ，容量仗 $C=11.1 \mathrm{t}$ である。

色替光時に和汀る output の比重変化を求的た結果を 図-3 の○印で示寸.

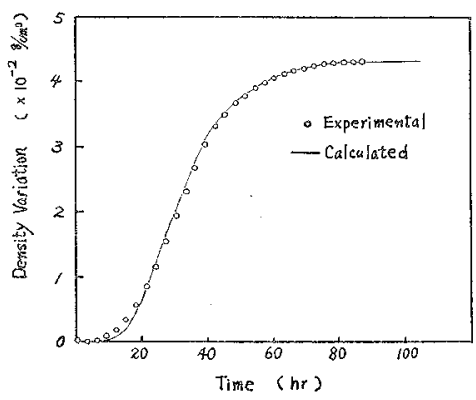

Fig. 3. Density variation proceeding with batch composition exchange.

単位関数 $E(t)$ に対する応答として (9) 式を用い, トレーサー策験の場合と同槺, 笑測値に最も近い $u_{x}$; $k_{x}$ 老求內た。 その結果, $u_{x}=0.249 \mathrm{~m} / \mathrm{hr}, k_{x}=0.20 \mathrm{~m}^{2}$ / hr の場合が実測值に最も一致した。この場合の計算值

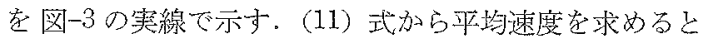
$u_{a}=0.249 \mathrm{~m} / \mathrm{hr}$ で上記の $u_{x}$ と全く一致する。

以上の結果から，タンク窟內のガラス生地の平均流速 弾に（11）式加ら求められる值で十分であることがわ 加灰。

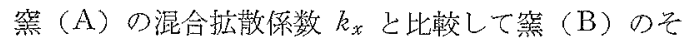
れは約 1/7である。また, 出始封間 (arrival time) $T_{a}$ も䇺 (A) は約 5 時間，䉥 (B) のそれは 9 時閒と

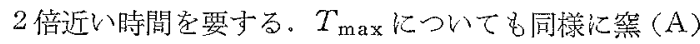


では 15 時間, 签 (B) では 25 時閒で岗った。

\section{4. 検討および考察}

\section{1 取出量が増減した場合}

取出量の橧隇による $k_{x}$ の変化はないものと考え, ル夕関数 $\delta(t)$ 拉よび単位関数 $E(t)$ に対する応答を調 ベた。

䇾（A）について，取出量を增減させた場合の $\delta(t)$ の空答を図-4に示声. 取出量の減少につれて $T_{\max }$ が 長くなり濃度の極大值 $S_{\max }$ が比例的汇減少与る。尘 在 $E(t)$ に対してはどう応答するか子图古に示す。取 出量の増加にと告なって立上りが鋭くなり，上り早く定 常值に近づく.

引上げられるガラスが色替えしようとするガラスによ って 90\% まで置き換えられる時間を办ると，㔍 (A) の $5.14 \mathrm{t} / \mathrm{hr}$ の取出量で注約 54 時閒必要とするが, 取 出量を $20 \%$ 増加した $6.168 \mathrm{t} / \mathrm{hr}$ にすることにより， 約 10 時閣短縮させることができるし，逆に $20 \%$ 減少 させ $4.112 \mathrm{t} / \mathrm{hr}$ にすると 16 時間余おく礼ることにな る。

次に珪砂中の水分が一定値より $2 \%$ 交互に增減させた

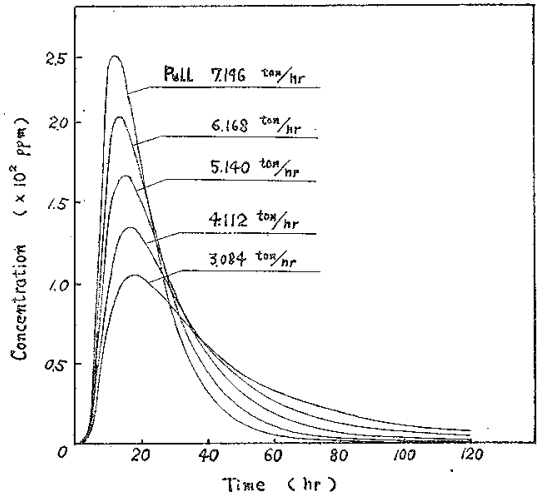

Fig. 4. Time dependence of concentration variation of $\mathrm{Li}_{2} \mathrm{O}$ in glass pulled out in various cases different in pull-rate.

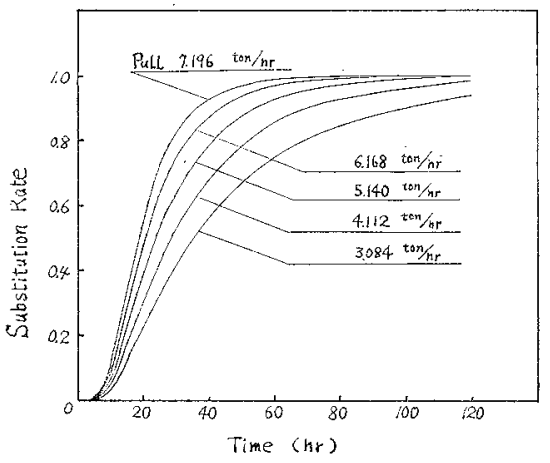

Fig. 5. Time dependence of glass substitution rate in various cases different in pull-rate.
場合にガラス生地の比重がどら变化するが学調べた。

図-6 は最初の $10 \mathrm{hr}$ は水分が $2 \%$ 增加（ガラス比重 で $+28 \times 10^{-4} \mathrm{~g} / \mathrm{cm}^{3}$ 増加）し，次の 10 時間は一定含水 分上り $2 \%$ 隇少 $\left(-28 \times 10^{-4} \mathrm{~g} / \mathrm{cm}^{3}\right.$ 比重隇）した理砂 を投入した場合の output のガラス生地の比重変動であ る.

一般にトレーサー実験では input の影響が output で検出されたとき，それまでの時間安出㕸め時間（arrival time）と呼んでいる。ここでは曲線の最初の部分 で，その微係数が急潡に変化する時点を称して，その閒 の㭙間定出始刘時䦔 $T_{a}$ と㭔ぶ. $T_{a}$ はこの場合取出量 の減少纪つれてわずか長くなる傾向に苏る。

结ぼ 20 時間後纪極大值が存在する。しか子、極大值 は取出量の増加に比例して大きなっている，極小值に達 する時間は取出量の減少にともなって 34 㭙間汃ら 42 時閭へと時間遜れが生ざてくる。極小值の絶体佔は図-6 に示すように取出量の増加によって加速度的に大きくな っている。

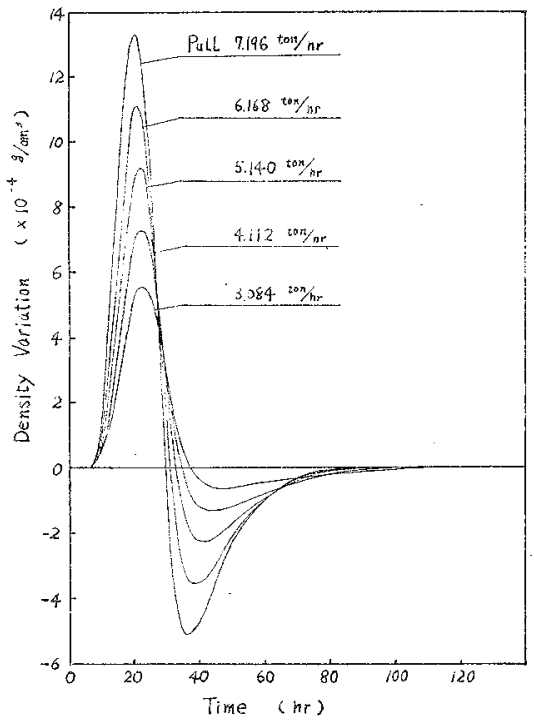

Fig. 6. Density variation of the pulled glass whose batch was fed with varying water content which was held at $2 \%$ higher than the standard for the first $10 \mathrm{hr}$ and was lowered $2 \%$ down than the standard for the next $10 \mathrm{hr}$ and then returned to the standard content.

\section{2 混合拡散係数が異なった場合}

混合拡散係数 $k_{x}$ によって䆶の混合特性曲線がどう変 化卞る加学図-7 亿示吉。

$k_{x}=1.34 \mathrm{~m}^{2} / \mathrm{hr}$ 注前述のトレーサ一実験で得られた

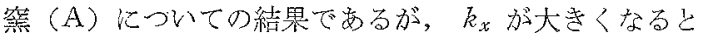
完全混合に近づくので，曲線恃鋭く立上り，極大值汇達

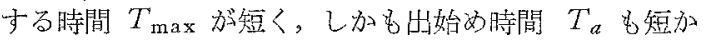
くなる。 


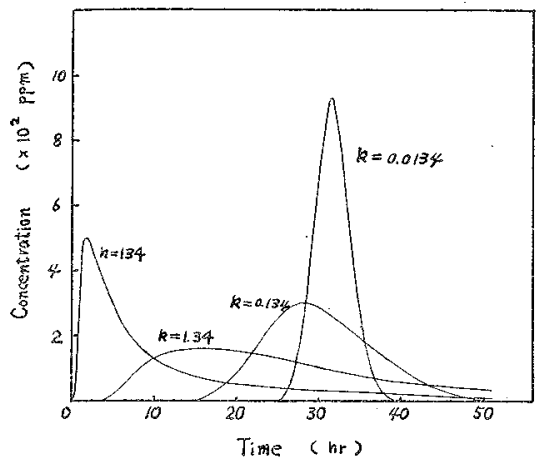

Fig. 7. Tracer concentration variation characteristics in various cases different in the value of mixing-diffusion coefficient $k_{x}$.

こ机原し， $k_{x}$ が小さくなると $T_{a}, T_{\max }$ ともに延 び，曲線は一旦平坦になるが，さらに $k_{x}$ が小さくなる と再び鋭く立上ってくる.

極限として，混合唯全く行なわれななくなると投入し た原料は学る时間後に一時机全部出払らことになる。こ のとき $T_{a}=T_{\max }$ となり, 䈏 (A) で約 32 時間と 字台。

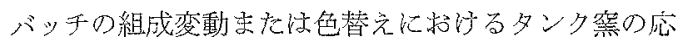
答特性ししては， $k_{x}$ が小さく， $T_{a}$ 㚙曼いことが要求 される、なせなら活，投入された原料がガラ大化就よび 均質化するに十分な時閐が必要であることと, 均翼化が 十分に行なわれた生地に未熔解のガラスが混大しないこ しも必要だからである。

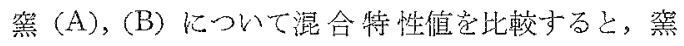
(A) の $k_{x}=1.34 \mathrm{~m}^{2} / \mathrm{hr}, T_{\max }=15$ 時閒で䂏 (B) では $k_{x}=0.20 \mathrm{~m}^{2} / \mathrm{hr}, T_{\max }=25$ 時間で离。.

事実，製品孛皎べても泡，コードなどの点で，その良
否仗すぐに判断できるほどの差異が認められた。

このようなガラスの均質化に関して窒（B）が非常に すぐれていることがわかる。

\section{5. 総括}

（1）ガラスタンク中の愹融ガラスの混合を，主とし て熱的执よび機械的な流れによる溜合索伴なった一種の 拡散過程しみなして，その混合拡散係数 $k_{x}$ をパラメ一 ターとしてタンク内の混合特性を検討する方法を提案し t.

（2） $k_{x}$ の值は，タンクの寸法，生地分ラスの軸方

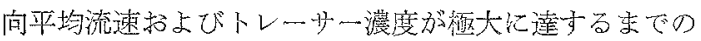
時閒の実測値 $T_{\max }$ を（8）式に適用することによって 算出される。

(3) タンク操作中に取出されるガラスの任意の物理

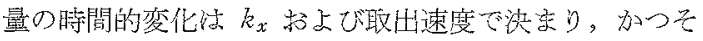
れによっで得られた混合特性曲線の㴍㥵怯 $k_{x}$ および $T_{\max }$ の值によって特徴づ讨られ，この䦗者がタンクの

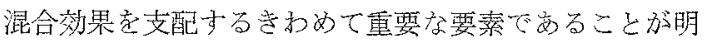
らかとなった。

\section{文献}

1) J.D. Lokay, Glass Ind. 46 [5] 258-61 (1965).

2) A.R. Cooper, J. Am. Ceram. Soc. 42 [2] 93-101 (1959).

3) D.M.H. Platt, Glass Ind. 89 [8] 428-32 (1968).

4) I. Sawai, Bull. Inst. Chem. Research, Kyoto Univ. 30, 1-14 (1952).

5) I. Sawai, M. Tashiro, K. Takahashi and K. Tabuchi, Proc. International Commission of Glass 1 , 96-120 (1954).

6) M.Kunugi, T. Takahashi and I. Sawai, Advan. Glass Tech. VI, 165-74 (1962).

7) 矢木, 宮内, 化学工学, 17,382 (1953).

[5/29/1970 受付 $]$ 